\title{
PHYSICAL ACTIVITY LEVELS AND SCREEN-BASED ACTIVITIES IN MACEDONIAN SCHOOL-AGED CHILDREN AND YOUNG ADOLESCENTS: AN IMPORTANT PUBLIC HEALTH PRIORITY
}

\section{POZIOM AKTYWNOŚCI FIZYCZNEJ I SPĘDZANIE CZASU PRZED EKRANEM U MACEDOŃSKICH DZIECI W WIEKU SZKOLNYM I MŁODOCIANYCH: WAŻNY PRIORYTET ZDROWIA PUBLICZNEGO}

\author{
Vera Simovska $^{1(\mathrm{~A}, \mathrm{~B}, \mathrm{C}, \mathrm{D}, \mathrm{E}, \mathrm{F})}$, Rozida Jakimoska-Jordanoska ${ }^{2(\mathrm{~A}, \mathrm{~B}, \mathrm{C}, \mathrm{D}, \mathrm{F})}$, Andrej Simovski ${ }^{3(\mathrm{E}, \mathrm{F}))}$ \\ ${ }^{1}$ MIT University Skopje, Faculty of Environmental Resource Management, Food Safety, Republic of Macedonia \\ ${ }^{2}$ Public Health Center, Department of School Medicine, Prilep, Republic of Macedonia \\ ${ }^{3}$ HEPA Macedonia National organization for the promotion of health-enhancing physical activity, Skopje, \\ Republic of Macedonia
}

Authors' contribution Wkład autorów: A. Study design/planning zaplanowanie badań B. Data collection/entry zebranie danych C. Data analysis/statistics dane - analiza i statystyki D. Data interpretation interpretacja danych E. Preparation of manuscript przygotowanie artykułu F. Literature analysis/search wyszukiwanie i analiza literatury G. Funds collection zebranie funduszy

\section{Summary}

Background. A wide range of studies have confirmed that insufficient physical activity levels and screen-based activities are key risk factors for overweight and obesity, chronic conditions and significant noncommunicable diseases (NCDs). More than $80 \%$ of the world's adolescent population is insufficiently physically active. The objectives of our cross-section study were to estimate the level of physical activity and sedentary behaviour in school-aged children and young adolescents and a significant correlation between two groups, physically active and inactive groups, and overweight and obesity development. Material and methods. The sample size involved 400 randomly selected children and adolescent from 14 to 18 years old. The International Questionnaire for assessment of Physical Activity (IPAQ-F) was used to monitor physical activity levels and screen-based activities. The statistical analysis involved descriptive statistics, Pearson Chi-square test and Logistic regression analysis using SPSS Statistics17.0. Results. There was a significant difference in vigorous and moderate intensity physical activity between two groups. Screen-based activities exerted the highest influence on the development of childhood obesity. However, the unhealthy nutrition had a significant impact on obesity in school-aged children (14-15 years old), much more than vigorous and moderate-to-vigorous physical activity. Conclusions. The prevention and treatment of overweight and obesity in children and adolescent require system-level approaches that would include the skills of sports physicians, registered dieticians/nutritionists, and sports coaches. They also need consistent and integrated messages and environmental support across all sectors of society, especially educational sector.

Keywords: physical activity levels, screen-time activity, obesity, school-aged children, adolescents, chronic disease prevention, health promotion

\section{Streszczenie}

Wprowadzenie. Wiele badań potwierdziło, iż niewystarczająca aktywność fizyczna i spędzanie czasu przed ekranem to kluczowe czynniki ryzyka pojawienia się nadwagi i otyłości, chorób przewlekłych i poważnych chorób nadciśnienia. Ponad 80\% populacji młodzieży na świecie jest niewystarczająco aktywna fizycznie. Celem naszych badań przekrojowych było oszacowanie poziomu aktywności fizycznej i siedzacego trybu życia wśród dzieci w wieku szkolnym i nastolatków oraz znalezienie korelacji między dwiema grupami, tj. grupą aktywną fizycznie i osobami nieaktywnymi oraz tymi z nadwagą i początkiem otyłości. Materiał i metody. Próby obejmowały 400 losowo wybranych osób (dzieci i młodzież) w wieku od 14 do 18 lat. W badaniu wykorzystano Międzynarodowy Kwestionariusz Oceny Aktywności Fizycznej (IPAQ - F) celem monitorowania aktywności fizycznej i działań związanych ze spędzaniem czasu przed ekranem. Do analizy danych użyto statystyki opisowej, test Pearsona Chi-square i analize regresji logistycznej z wykorzystaniem programu SPSS Statistics17.0. Wyniki. Zaobserwowano istotną różnicę w aktywności fizycznej o dużej i umiarkowanej intensywności pomiędzy dwiema grupami. Najwyższy wpływ na rozwój otyłości u dzieci miało długie spędzanie czasu przed ekranem. Jednakże, w rozwoju otyłości u dzieci w wieku szkolnym (14-15 lat), dużo większe znaczenie niż intensywna czy umiarkowanie - intensywna aktywność fizyczna, okazała się mieć niezdrowa dieta. Wnioski. Zapobieganie i leczenie nadwagi i otyłości u dzieci i młodzieży wymagają podejścia systemowego, wykorzystującego umiejętności lekarzy sportu, dietetyków / dietetyków, trenerów sportowych, a także spójnych i zintegrowanych komunikatów oraz wsparcia środowiska we wszystkich sektorach życia społecznego, w szczególności w sektorze edukacyjnym.

Słowa kluczowe: poziom aktywności fizycznej, spędzanie czasu przed ekranem, otyłość, dzieci w wieku szkolnym, młodzież, zapobieganie chorobom przewlekłym, promocja zdrowia
Tables: 4

References: 26

Submitted: 2017 Jun 26

Accepted: 2017 Sep 12 ka R, Simovski A. Physical activity levels and screen-based activities in Macedonian school-aged children and young adolescents: An important public health priority. Health Problems of Civilization. 2017; 11(3): 173-179. doi: 10.5114/hpc.2017.70002.

Address for correspondence / Adres korespondencyjny: Simovska Vera, University MIT Skopje, Square Macedonia, City Gallery, 1000 Skopje, Republic of Macedonia, e-mail: vera.simovska@mit.edu.mk, phone: + 38978226009

Copyright: (C) 2017 Pope John Paul II State School of Higher Education in Biała Podlaska, Vera Simovska, Rozida Jakimoska-Jordanoska, Andrej Simovski. This is an Open Access journal, all articles are distributed under the terms of the Creative Commons Attribution-NonCommercial-ShareAlike 4.0 International (CC BY-NC-SA 4.0) License (http://creativecommons.org/licenses/by-nc-sa/4.0/), allowing third parties to copy and redistribute the material in any medium or format and to remix, transform, and build upon the material, provided the original work is properly cited and states its license. 


\section{Introduction}

A wide range of studies have confirmed that insufficient levels of physical activity are some of the leading risk factors for overweight and obesity, chronic condition and several noncommunicable diseases (NCDs) such as cardiovascular diseases (CVD), type 2 diabetes (T2DM), and certain cancers [1, 2]. Further, there is an active link between screen-based activities (screen time, smart phone, tablet, TV) and adiposity in children and adolescents [3].

Physical activity during childhood includes dance, play, games, sports, active transport such as walking to school, cycling, active recreation and planned exercise in the context of family, school, as well as community activities and physical education [4].

Scientific data confirm that over $60 \%$ of the world population is sedentary or not active enough to gain health benefits. The World Health Organization (WHO) research evidence has identifies that globally over $80 \%$ of children and young adolescents aged 11-17 years were insufficiently physically active in 2017 [3]. Girls were less active than boys, and they are not meeting the WHO recommendations [5]. Besides, physical activity declines significantly with age during adolescence. In 2012, only 1 in 5 children in the European Union reported taking part in a regular moderate-to-vigorous intensity physical activity (MVPA) [6].

Adequate levels of physical activity assist children and young adolescents to develop basic cognitive and social skills, as well as musculoskeletal health (bones, muscles and joints), a healthy cardiovascular system (heart and lungs), to develop neuromuscular awareness (coordination and movement control) and maintain a healthy body weight. Physical activity has also been associated with psychological benefits in young people by improving their control over symptoms of anxiety and depression. It has also been suggested that physically active young people more readily adopt other healthy behaviours (avoidance of tobacco, alcohol and drug use) and demonstrate higher academic performance at school.

The WHO described the action needed to increase physical activity worldwide adopting the "Global Strategy on Diet, Physical Activity and Health" in 2004 [7] and publishing the "Global Recommendations on Physical Activity for Health" in 2010 with a focus on primary prevention of NCDs through physical activity [5].

The physical activity recommendation for children and young adolescents aged 5-17 years old includes at least 60 minutes of moderate- to vigorous-intensity physical activity (MVPA) daily and amounts of physical activity higher than 60 minutes providing additional health benefits. Most of the daily physical activity should be aerobic. Moderate-to-vigorous activity (MVPA) should incorporate those activities that strengthen muscle and bone at least 3 times per week [5].

The WHO proposes different policy options to reach the recommended levels of physical activity globally such as the development and implementation of national guidelines for health-enhancing physical activity (HEPA strategy), the integration of physical activity within other related policy sectors in order to secure that policies and action plans are coherent and complementary, the use of mass media to raise awareness of the benefits of being physically active, and the surveillance and monitoring of actions to promote physical activity [8].

A large number of NCDs are preventable through modification of the known high causal behavioural risk factors: physical inactivity and poor diet in school-aged children and young adolescent. Children's behaviour depends much on their physical and social environment. Obesity can be seen as a typical response to an obesogenic environment [9]. Several societal and environmental factors which are linked to urbanization can discourage people from becoming more active, i.e. lack of parks, sidewalks and sports and recreation facilities, pollution, and high-density traffic [10]. Combining behavioural, social and medical theories is the most practical approach to develop strategies and programmes for NCDs prevention and health promotion [11].

In 2015, the WHO prepared Physical activity strategy for the WHO European Region, 2016-2025 [4]. The European Commission was adopted EU Action Plan on Childhood Obesity, 2014-2020 [9], which recognizes the beneficial impact of health promotion and disease prevention on both citizens and health systems, and the importance of physical activity promotion as well as a healthy diet in reducing the risk of chronic conditions and NCDs [10]. One of the primary documents for future progress is the European Food and Nutrition Action Plan 2015-2020 [12].

The Republic of Macedonia needs to address growing NCDs epidemic through health promoting partnerships, strategy and programme. The first research study on health-risk behaviours among the Macedonian population including school-aged children (CINDI Youth programme) was carried out in the year 2002 [13] using the locally adapted WHO CINDI Health Monitor questionnaire. The evidence has led to initiatives that resulted in developing and implementing a national intervention scheme for NCDs prevention and control and health promotion using the WHO CINDI Protocol in the Republic of Macedonia with an aim to change population behaviour. Physical activity and nutrition education of youth were in the focus of the modern healthcare and educational system [14]. 


\section{The aims of our research}

1. To examine the nutritional status, physical activity levels and screen-based activities in of 400 study participants divided in two groups: group A of school-aged children (14-15 years old), and group B of young adolescents (17-18 years old);

2. To assess the correlation between physically active and inactive participants in group A and group B;

3. To estimate the relationship between physical activity levels and screen-based activities with overweight and obesity in both groups of children and adolescents.

\section{Material and methods}

The cross-sectional study was conducted from January to May 2016 year in the group of 400 school-aged children and young adolescents from primary and secondary school in the Republic of Macedonia. A significant correlation between physical activity levels including screen-based activities, and overweight and obesity in school-aged children and younger adolescent were examined. The International Questionnaire for assessment of Physical Activity Levels (IPAQ)-short version was used as a suitable questionnaire in national and regional surveillance systems.

The anthropometric measurements include body weight and height, and body mass index $\left(\mathrm{BMI} \mathrm{kg} / \mathrm{m}^{2}\right)$ presented in percentile using the World Health Organization Child Growth Standards [15].

The total sample involved 400 randomly selected children and adolescents aged 14 to 18 . They were divided into two groups of school-aged children (14-15 years old) and young adolescents (17-18 years old), with an equal proportion of both genders: boys and girls, selected by a double-blind method. After the anthropometric measurements of all the study participants using WHO methodology [15], they filled in the questionnaires about their physical activity levels including screen-based activities.

1. Anthropometric data: body height, weight, and body mass index $\left(\mathrm{BMIkg} / \mathrm{m}^{2}\right)$ presented in percentile form using the WHO Child Growth Standards. In school-aged children and young adolescents aged 5-19 years, the overweight and obesity are defined as the proportion of children with a sex- and age-specific body mass index for age value above +1 Z-score and above +2 Z-scores of the WHO recommended Growth Reference [15].

2. Physical activity levels and screen-based activities are measured using self-reported questionnaires: the International Questionnaire for assessment of Physical Activity (IPAQ)-short version [16, 17]. "Last 7 days recall" or IPAQ-short form is recommended for national and regional monitoring and is not designed to provide a detailed assessment of physical activity in all domains. It was used to estimate time spent in activities of various levels of intensity, and to rank the participants in levels of reported activity as well as time spent in screen-based activities (hours per week/minutes per day). The IPAQ-short version included vigorous-intensity physical activity (VIPA), moderate-to-vigorous (MVPA), light intensity physical activity (LIPA), and non-exercise (physical inactivity) or screen-based activities.

The statistical analysis based on descriptive statistics, Pearson Chi-square test and Logistic regression analysis using SPSS Statistics 17.0. The level of significance was $\mathrm{p}<0.05$.

\section{Results:}

Body Mass Index in a healthy range (BMI $\left.=18.5-24.9 \mathrm{~kg} / \mathrm{m}^{2}\right)$ was estimated in $79 \%$ of 400 study participants. The prevalence of undernutrition was $4.25 \%$, and the prevalence of overweight and obese was $16.75 \%$ (table 1 ).

Table 1. Descriptive parameters of nutritional status of school-aged children (14-15 years old) - group A

\begin{tabular}{|c|c|c|c|c|c|c|c|}
\hline Parameters & No & $\mathbf{X}$ & $\begin{array}{c}\text { Confidence } \\
\mathbf{- 9 5 . 0 0 \%}\end{array}$ & $\begin{array}{c}\text { Confidence } \\
\mathbf{+ 9 5 , 0 0 \%}\end{array}$ & Min & Max & St. Dev. \\
\hline Height $(\mathrm{m})$ & 200 & 1.70 & 1.69 & 1.71 & 1.50 & 1.96 & 0.08 \\
\hline Weight $(\mathrm{kg})$ & 200 & 62.84 & 61.24 & 64.43 & 43.00 & 104.00 & 11.44 \\
\hline BMI kg/m ${ }^{2}$ & 200 & 21.76 & 21.30 & 22.23 & 15.30 & 34.20 & 3.33 \\
\hline Percentile & 200 & 62.66 & 59.16 & 66.17 & 2.60 & 99.70 & 25.14 \\
\hline
\end{tabular}

In the first group- $\mathrm{A}$, consisting of 200 school-aged children (14-15 years old), the prevalence of undernutrition was $1 \%$, and $77 \%$ had a healthy range of BMIkg/m². $13 \%$ were overweight and $9 \%$ were obese of all the study participants in this group (Figure 1). 


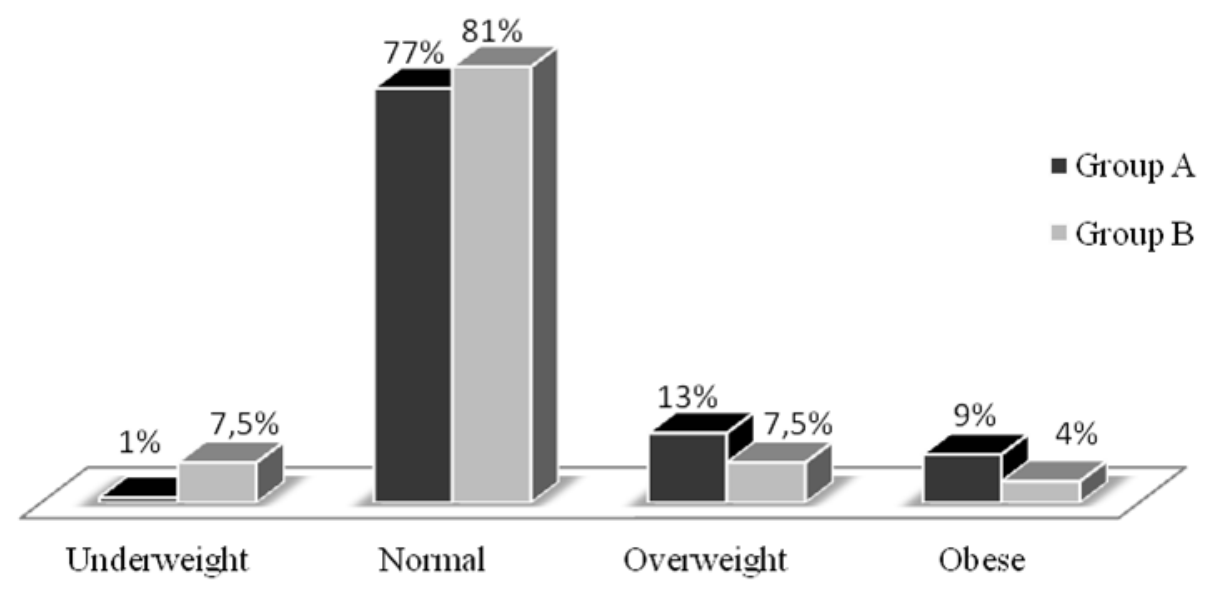

Figure 1. BMI kg/m² distribution of study participants in group A and group B

Following the distribution of Pearson Chi-square $=16.94(\mathrm{p}<0.001)$, there was a statistical significance between the nutrition status of the study participants in both experimental groups A and B.

In the same group A, 82.5\% followed vigorous and moderate-to-vigorous physical activity (MVPA) daily, and amounts of physical activity were higher than 60 minutes/day. $17.5 \%$ of the study participants were physically inactive (Table 2).

Table 2. Descriptive parameters of the physical activity levels of school-aged children (14-15 years old) - group A

\begin{tabular}{|c|c|c|c|c|}
\hline Physical Activity Levels & Day/week & Hours/day & No. participants & \% \\
\hline Vigorous intensity & 3.49 & 1.37 & \multirow{2}{*}{165} & \multirow{2}{*}{82.5} \\
\hline Moderate-to-vigorous intensity (MVPA>60min) & 2.65 & 1.12 & & \multirow{2}{*}{35} \\
\cline { 1 - 3 } Screen-based activity with Light Intensity (LIPA) & 7.0 & 4.39 & 17.5 \\
\hline
\end{tabular}

In the second group - B, consisting of 200 young adolescents (17-18 years old), the prevalence of undernutrition was $7.5 \%$, and $81 \%$ of all participants had a healthy body weight. Also, $7.5 \%$ were overweight and $4 \%$ were obese of all study participants in this group (Figure 1).

Table 3. Descriptive parameters of the nutritional status of older adolescent (17-18 years old) -group B

\begin{tabular}{|c|c|c|c|c|c|c|c|}
\hline Parameters & No & $\mathbf{X}$ & $\begin{array}{c}\text { Confidence } \\
\mathbf{- 9 5 . 0 0 \%}\end{array}$ & $\begin{array}{c}\text { Confidence } \\
\mathbf{+ 9 5 , 0 0 \%}\end{array}$ & Min & Max & St. Dev. \\
\hline Height (m) & 200 & 1.69 & 1.68 & 1.70 & 1.47 & 1.88 & 0.09 \\
\hline Weight (kg) & 200 & 62.81 & 61.10 & 64.51 & 45.00 & 111.00 & 12.20 \\
\hline BMI kg/m ${ }^{2}$ & 200 & 22.13 & 21.44 & 22.83 & 9.30 & 73.20 & 5.01 \\
\hline Percentiles & 200 & 44.08 & 40.08 & 48.08 & 0.40 & 99.30 & 28.68 \\
\hline
\end{tabular}

Nearly 59.5\% of all the younger adolescents - group B followed vigorous and moderate-to-vigorous physical activity (MVPA) daily and amounts of physical activity were higher than 60 minutes/day. The higher percentage, $40.5 \%$ of all the younger adolescents spent their time in screen-based activity or they were physically inactive (Table 4).

Table 4. Descriptive parameters of the physical activity levels of older adolescents (17-18 years old) - group B

\begin{tabular}{|c|c|c|c|c|}
\hline Physical Activity Levels & Day/week & Hours/day & No. participants & \% \\
\hline Vigorous intensity & 2.4 & 0.8 & \multirow{2}{*}{5} & 5.5 \\
\hline Moderate-to-vigorous intensity (MVPA>60min) & 2.7 & 1.0 & & \\
\hline Screen-based activity with Light Intensity (LIPA) & 7.0 & 4.9 & 81 & 40.5 \\
\hline
\end{tabular}

A significant impact on the development of child obesity had screen-based activities accompanied by light intensity physical activity (LIPA). Statistical significance was estimated between children obesity and the analyzed independent indicators, for example, the levels of physical activity including vigorous and moderateto-vigorous physical activity (MVPA), light intensity physical activity (LIPA) and screen-based activity. 
Following the distribution of Pearson Chi-square $=26.59(\mathrm{p}<0.001)$, there was a significant difference in vigorous intensity physical activity and MVPA between two groups, A and B.

The screen-based activity had the highest influence on the development of obesity in school-aged children and young adolescent (Wald=2.81; $\mathrm{p}=0.09$ ). The vigorous and MVPA has the lowest impact on the development of obesity (Wald score $=0.000 ; p=0.99$ ).

In accordance with our study results, group A had a higher percentage of physically active participants with vigorous and MVPA than group B, but also the higher number of obese school-aged children than group B. It was the consequence of unhealthy nutrition of school-aged children, whose diet included sweetness food (pasta, rise and potatoes), crisps and soft drinks.

\section{Discussion}

It is known that morbidity and mortality from main NCDs such as CVD, T2DM, and certain obesity-related cancers can be prevented by changes in behaviour risk factors associated with the lifestyle of the population, primarily by reducing unhealthy diet and increasing physical activity levels. As for the physical inactivity, the WHO proposed target is a $10 \%$ relative reduction in the prevalence of insufficiently physically active youth and adults by 2025 [4].

According to clinical and epidemiology studies conducted over the past ten years in the Republic of Macedonia, it turns out that the reduced levels of physical activity were found in $50 \%$ of girls aged from7 to 12 years [18].

The study results conducted in 2012 among 580 Macedonian school-aged children and adolescents targeting those aged 10-18 years showed that a higher income has an impact on the engagement in organized sports activities and a low effect on participating in moderate-intensity physical activities such as brisk walking and running as well as in MVPA such as cycling [19]. Also, the results showed that $59 \%$ of the children and adolescents followed vigorous and moderate-to-vigorous physical activity such as organized sports activities. Only $28 \%$ of them exhibited a low level of physical activity, especially girls.

For that reason, prevention and treatment of paediatric overweight and obesity require system-level approaches that would involve the skills of sports physicians, registered dieticians, sports coaches. Consistent and integrated messages and environmental support across all sectors of society, especially the educational sector, are also needed to achieve a sustained dietary and physical activity behaviour change $[20,21]$.

The secondary prevention should emphasize family-based, developmentally appropriate approaches that include nutrition education and dietary counselling including physicians, parenting skills, behaviour strategies popularized in social media $[22,23]$ and physical activity promotion programmes for a healthy lifestyle.

The physical activity strategy aims to inspire governments and stakeholders to work towards increasing the level of physical activity among all citizens of the European Region by: promoting physical activity and reducing sedentary behaviours; ensuring an enabling environment that supports physical activity through engaging and safe built environments, accessible public spaces and infrastructure; providing equal opportunities for physical activity regardless of gender, age, income, education, ethnicity or disability; and removing barriers to and facilitating physical activity [4].

\section{Conclusion}

The most vital strategic approach is to develop an innovative model including nutritional and physical activity education programme in the Republic of Macedonia $[18,24]$. Youth sports are a significant source of physical activity contributing $23 \%$ to $60 \%$ of daily MVPA. As for screen-based activities, including TV, smart phone, tablet, and computers games for school-aged children and young adolescents, it is recommended that they spend no more than 2 hours per day.

Interventions targeted at the individual level are not likely to be sufficient in addressing the adolescent obesity epidemic without changes in social norms and the environment. The power of the community-wide programmes is to influence the community as a whole so that the desired behaviours easily combine such features as leadership and partnership [25]. The priority areas include: providing leadership and coordination for the promotion of physical activity, supporting the development of children and adolescents in healthy behaviour including balanced nutrition as well as supporting action through monitoring, surveillance, the provision of tools, enabling platforms, evaluation and research [26]. From those reasons, the most appropriate seems to be the longitudinal studies. 


\section{References:}

1. Declaration of First Global Ministerial Conference on Healthy Lifestyles and Noncommunicable Disease Control, Moscow: 28-29 April 2011. [cited 2011 May 20]. Available from:http://www.who.int/nmh/events/ moscow_ncds_2011/conference_documents/moscow_declaration_en.pdf.

2. WHO Global Action Plan for the Prevention and Control of Noncommunicable Diseases 2013-2020. World Health Organization, Geneva: 27 May 2013. [cited 2015 Jun 12]. Available from: http://www.who.int/nmh/ publications/ncd-action-plan/en/.

3. World Health Organization. Global Health Observatory (GHO) data. Prevalence of insufficient physical activity. http://www.who.int/gho/ncd/risk_factors/physical_activity_text/en

4. Physical activity strategy for the WHO European Region, 2016-2025 (EUR/RC65/9), WHO Regional Office for Europe: Copenhagen 2015. [cited 2014 July 28]. Available from:http://ec.europa.eu/health//sites/health/ files/nutrition_physical_activity/docs/childhoodobesity_actionplan_2014_2020_en.pdf.

5. WHO Global Recommendations on Physical Activity for Health. World Health Organization, Geneva: 2010. [cited 2015 Jun 12]. Available from: http://www.who.int/dietphysicalactivity/publications/9789241599979/ en/.

6. WHO Population-based approaches to childhood obesity prevention. World Health Organization, Geneva: 2012. [cited 2012 Nov]. Available from:http://www.who.int/dietphysicalactivity/PA-promotionguide-2007. pdf?ua=1.

7. WHO Global Strategy on Diet, Physical Activity and Health. World Health Organization, Geneva: 2004. [cited 2010 May 11]. Available from: www.who.int/dietphysicalactivity/strategy/eb11344/strategy_english_web. pdf.

8. A guide for population-based approaches to increasing levels of physical activity: implementation of the WHO Global Strategy on Diet, Physical Activity and Health.World Health Organization, Geneva: 2007.

9. EU Action Plan on Childhood Obesity 2014-2020. Brussels: European Union; 2014. [cited 2015 June 12]. Available from: https://ec.europa.eu/health/sites/health/files/nutrition_physical_activity/docs/ childhoodobesity_actionplan_2014_2020_en.pdf.

10. Study on the implementation of the EU Action Plan on Childhood Obesity 2014-2020. The childhood Obesity Study. [cited 2017 February 21]. Available from: https://www.eu2017.mt/Documents/Reports/midterm\%20 evaluation\%20APCO\%20report\%20Draft.pdf.

11. Puska P, Vartiainen E, Laatikainen T, Jousilahti P, Paavola M. The North Karelia Project-From North Karelia to national action. Publications of the National Institute for Health and Welfare, Helsinki: National Institute for Health and Welfare. Helsinki University Printing House; 2009.

12. European Food and Nutrition Action Plan 2015-2020. WHO Regional Office for Europe: Copenhagen, Denmark. [cited 2016 May 9]. Available from:http://www.euro.who.int/_data/assets/pdf_ file/0008/253727/64wd14e_FoodNutAP_140426.pdf.

13. Simovska V. WHO CINDI Program in Republic of Macedonia, 2001-2005. [ cited 2007 May]. Skopje: 2005. Available from: http://www.cindi.makedonija.com.

14. Position of the Academy of Nutrition and Dietetics: Interventions for the Prevention and Treatment of Pediatric Overweight and Obesity. Journal of the Academy of Nutrition and Dietetics, 2013; 113(10):13751394.

15. WHO Child Growth Standards: Length/Height-for-age, Weight-for-age, Weight-for-length, Weight-for-height and Body Mass Index-for age. World Health Organization, Geneva; 2006.

16. International Physical Activity Questionnaire. [cited 2015 Apr 11]. Available from: www.ipaq.ki.se.

17. Lee PH, Macfarlane DJ, LamTH, Stewart SM. Validity of the international physical activity questionnaire short form (IPAQ-SF): A systematic review.International Journal of Behavioral Nutrition and Physical Activity $2011 ; 8: 115$.

18. Simovska V. Noncommunicable disease prevention and health promotion through physical activity. Journal of Macedonian Medical Association. Mak. Med. Pregled. 2004; 57(suppl.60): 30-35.

19. Simovska V. et al. Effect of socioeconomic indicators on dietary habits, physical activity (PALs) and BMI kg/ $\mathrm{m}^{2}$ in Macedonian youth. In: Bookof Abstracts and Original Papers, The $\mathrm{V}^{\text {th }}$ Congress of Sports Medicine and Sports Sciences of Serbia with International participations, Belgrade, 2012. p.19-21.

20. Food and Nutrition Policy for Schools: A Tool for the Development of School Nutrition Programmes in the WHO European Region. WHO Regional Office for Europe: Copenhagen, 2006, Denmark. [cited 2014 May 10]. Available from:http://www.euro.who.int/_data/assets/pdf_file/0019/152218/E89501.pdf. 
21. European Commission: WHO Health-Enhancing Physical Activity development in the European context. High Level meeting in nutrition and physical activity. Brussels, 2016. [cited 2016 Sep]. Available from:http:// ec.europa.eu/sport/policy/cooperation/expert-groups-2014-2017_en.htm.

22. Healthy Eating Apps. The beta version of high school nutrition program "Eat Move Win"; 2014 Dairy Council of California Programs [cited 2014]. Available from: www.EatMoveWin.org

23. Simovska $V$. The presence of risk factors for cardiovascular diseases in the family and early detection in their children.(Post-graduate subspecialist thesis, Faculty of Medicine, University of Belgrade; 1993).

24. Simovska V, Damjanovska M, Vidin M. "Skill for health" development through teaching for physical and health education-a part of National Strategy/Program for the promotion of health-enhancing physical activity in Republic of Macedonia. The Review for scientific and professional issues of physical culture Fizickakultura2007; 3(2): 99-103.

25. Pbert L, Druker S, Barton B, Schneider KL, Olendzki B, Gapinski MA.A School-Based Program for Overweight and Obese Adolescents: A Randomized Controlled Trial. J Sch Health.2016; 86(10): 699-708. doi: 10.1111/ josh.12428.

26. Simovska V, Stojanovska V, Vidin M. Modern aspects of health education in the national education programme in the Republic of Macedonia. Ist International Symposium for Physical Education and Sport of Students "Issues and perspectives", Skopje 2005. The Book of papers, 2005 Skopje: Faculty of Physical Culture, Center for physical education. p.69-70. 